\title{
INCORPORATION OF UNCERTAINTY IN TECHNICAL AND ECONOMIC ANALYSIS OF A FELLER-BUNCHER
}

\author{
Danilo Simões $^{1 *}$; Ricardo Hideaki Miyajima²; Rodrigo Petrongari Tonin ${ }^{2}$; Paulo Torres Fenner²; \\ Gislaine Cristina Batistela ${ }^{1}$ \\ ${ }^{1}$ State University of São Paulo, Itapeva, Sao Paulo, Brazil - danilo.simoes@unesp.br*; gislaine.batistela@unesp.br \\ ${ }^{2}$ State University of São Paulo, School of Agriculture, Botucatu, Sao Paulo, Brazil - richidetoshimiyajima@ hotmail.com; \\ rptonin@fca.unesp.br; fenner@fca.unesp.br
}

Received for publication: 19/11/2017 - Accepted for publication: 07/04/2018

\begin{abstract}
The constant technical and economic analysis of timber harvesting operations is essential and determining, due to the monetary magnitude. Traditionally, these analyses are conducted deterministically, which does not allow obtaining values with probabilities of occurrence. Considering this issue, stochastic models were built in order to analyze the behavior of probabilistic production cost in felling operations with feller-buncher, through the Monte Carlo method. The study was conducted in the Central-West region of the state of São Paulo in a forest of Eucalyptus sp., with six years of age, planted in $3 \times 2 \mathrm{~m}$ spacing. Technical analysis was based on the study of time and movements, which determined the effective productivity and economy in the hourly operating cost of the feller-buncher and in the production costs of the operation. Due to uncertainties, probability distributions were assigned to these results, which identified the most relevant variables and quantified the probabilities of the production cost. The results demonstrated that the fuel cost had a statistically significant strong positive correlation coefficient $\left(\rho_{s}=0.91\right)$ (p-value $<0.01$ ). The hourly cost, consequently, was directly proportional to the production cost of the operation. The production cost of the operation in flat relief was $18 \%$ lower than the production cost of the operation in undulating relief.
\end{abstract}

Keywords: Harvest, time and movements, productivity, operational risk, cost.

\section{Resumo}

Incorporação da incerteza na análise técnica e econômica de um feller buncher. A constante análise técnica e econômica das operações de colheita florestal possui caráter essencial e determinante, devido à magnitude dos valores monetários. Tradicionalmente, essas análises são realizadas de forma determinística, o que não permite a obtenção de valores com probabilidades de ocorrência. Nesse sentido, foram construídos modelos estocásticos para analisar o comportamento do custo probabilístico de produção na operação de derrubada com feller buncher, por meio do método de Monte Carlo. O estudo foi conduzido na região Centro-Oeste do estado de São Paulo em uma floresta de Eucalyptus sp. com seis anos de idade, plantada em espaçamento de 3 x $2 \mathrm{~m}$. A análise técnica foi pautada no estudo de tempos e movimentos, determinando-se a produtividade efetiva e a econômica no custo operacional horário do feller buncher e nos custos de produção da operação. Por conterem incertezas, a esses resultados, foram atribuídas distribuições de probabilidade, que permitiram identificar as variáveis mais relevantes e quantificar as probabilidades do custo de produção. Constatou-se que o custo com combustível possui coeficiente de correlação positiva forte $\left(\rho_{s}=0,91\right)$, estatisticamente significativo (valor $\mathrm{p}$ $<0,01)$. O custo horário, por consequência, foi diretamente proporcional ao custo de produção da operação. $\mathrm{O}$ custo de produção da operação em relevo plano foi $18 \%$ inferior ao custo de produção da operação em relevo ondulado.

Palavras-chaves: Colheita, tempos e movimentos, produtividade, risco operacional, custos.

\section{INTRODUCTION}

In the economic context, the required equipment for mechanized timber harvesting are considered constant inputs. Moreover, they must be technically efficient since this affects the production level and, consequently, the production costs. For that matter, Leite et al. (2013) and Leite et al. (2014) stress that such efficiency is impacted by several factors, such as the individual volume per tree and slope of the terrain, which interact with each other either isolated or dynamically. This justifies the need of knowing in detail the effects of these variables so as to plan operations aiming at reducing costs and settling production.

FLORESTA, Curitiba, PR, v. 48, n. 3, p. 403-412, jul/set. 2018

Simões. D. et.al.

ISSN eletrônico 1982-4688

DOI: $10.5380 /$ rf.v48i3.56404 
The determination and quantification of these influential variables are determining factors for forest planning and success of operations, which contribute greatly to the optimization and economic viability of harvesting activities. This is so mainly because of Brazil's position as the fourth among the countries with the highest production cost (OLIVEIRA JÚNIOR et al., 2009; SANTOS et al., 2016).

In mechanized timber harvesting operations, one of the most used equipment for the cutting step is the fellerbuncher, developed in North America. This machine is a tractor with rotated tires or mats, and hydraulic arm and head, used to cut various trees in one operating cycle. This function is possible due to a system of accumulation of trees fitted in its own head (SPINELLI et al., 2007; OLIVEIRA JUNIOR et al., 2009; HIESL; BENJAMIN, 2013).

Therefore, due to adjustments made to the operationalization of the feller-buncher in South America and the several factors that affect the operational productivity and, consequently, timber harvesting costs, technical and economic values can vary considerably for each working condition. Thus, the uncertainty can be incorporated into technical-economic studies directed to timber harvesting, aiming at the management of forest resources, through the probability of occurrence of values, which allow to describe the behavior of the most relevant variables.

Since the uncertainties are common, the acknowledgement of the impact that these can cause generates opportunities to optimize the production systems, creating ways to make them more controllable (CHENG; ROY, 2010; PAJARES; LOPEZ-PAREDES, 2011). One of the ways to incorporate the uncertainties of a forestry project is through the Monte Carlo method. According to Loizou and French (2012), when considering this incorporation, the analysis of a project is no longer based on a deterministic result, but through an area that represents the uncertainty, with the possibility of understanding and quantifying their effects on project budgets (KWAK; INGALL, 2009).

The usage of the Monte Carlo method enables the incorporation of technical and economic elements, essential to analyze the sensitivity of the most relevant variables of a stochastic model. Additionally, it allows the obtainment of probability distributions and of the range of uncertainties, making it possible to measure the risk presented in the tails of the distribution set.

For that matter, and considering that the uncertainties are related to calculation methodologies, to all the data and to the environment of a forest stand, this study aims at building stochastic models to analyze the behavior of the probabilistic cost of the production in the felling operation with feller-buncher in two classes of slope terrain through the Monte Carlo method.

\section{MATERIALS AND METHODS}

\section{Area of study}

The study was conducted in the Central-West region of the state of São Paulo, Brazil, $\left(23^{\circ} 06^{\prime} \mathrm{N}, 48^{\circ} 36^{\prime} \mathrm{E}\right)$, in the summer. According to the Köppen-Geiger climate classification, the climate of the area is temperate humid, with dry winter and hot summer, and annual average temperature of $19.7^{\circ} \mathrm{C}$. In general, the area has an average relative humidity around $74 \%$, with average annual rainfall of $1,372.7 \mathrm{~mm}$ and a relatively dry season from July to September. Geographically, it has predominantly Yellow Red Latosol, Psamytic Distrophic (SANTOS et al., 2013). Furthermore, it has separate slope classes according to the Brazilian soil classification. Therefore, it has 0 to $3 \%$ of flat relief and 8 to $20 \%$ of undulating relief, with strongly acid soils $(\mathrm{pH}<4.5)$.

In this area, there was a stand of six-year-old Eucalyptus sp., intended for the production of plates. The stand was planted in $3 \times 2 \mathrm{~m}$ spacing and had an average diameter at breast height (DBH) of $15.94 \pm 3.85 \mathrm{~cm}$, average height of $24.58 \pm 4.78 \mathrm{~m}$ and average volume of $0.23 \pm 0.11 \mathrm{~m}^{3}$ per tree, conducted under high shaft. The wood volume was estimated from the forest inventory, considering the stratified random sampling.

\section{Data collection}

The harvest system was of long logs, thus, a John Deere 903k feller-buncher was used, with 13,331 accumulated hours of use, 294 horsepower, wheeled conveyor, hoist for maximum range of $6.7 \mathrm{~m}$ and FS22B felling head, with $558.8 \mathrm{~mm}$ cutting capacity and accumulation capacity of $0.48 \mathrm{~m}^{2}$. The work extension of the fellerbuncher was composed of three tree rows, six meters wide. The bundles of trees were dumped on the ground at an angle of $90^{\circ}$ in relation to the alignment of the planting, in order to facilitate the next step of extraction.

Working time data were registered through time and movements studies, through continuous-time timing. The operating cycle of the equipment was divided by working elements, which were performed in a regular sequence, contributing effectively to the timber harvesting operation. The cycle is represented by the time spent to fell the trees, dump the bundles of trees on the ground, return to cutting position and accumulate the bundles of trees.

The time data of each working cycle element were submitted to the Shapiro-Wilk test in order to verify the assumption of normality. For comparison of the mean times of each element, in each relief and between them, the analysis of variance was applied (ANOVA), complemented with Tukey test at $5 \%$ level of significance. 
According to Mousavi (2012), a sample shall be timed in order to obtain a conclusion with a certain degree of statistical validity. In this perspective, 50 operating cycles were observed for a preliminary estimate of the sample size in both reliefs, in order to obtain a sufficiently representative sample. The sample was taken from the mean times of the work cycle elements $(\bar{x})$ and standard deviation of the sample (s) (STEVENSON, 2001), at 95\% confidence level and 5\% of error, as described in Equation 1.

$$
n=\left(\frac{z s}{a \bar{x}}\right)^{2}
$$

In which:

$n$ - sample size;

$Z$ - number of standard deviations in a normal distribution necessary to obtain the desired confidence level;

$s$ - standard deviation of the sample;

$a$ - percentage of precision desired;

$\bar{x}$ - sample mean.

\section{Technical analysis}

From the relationship between effective time of work and volume of trees cut, the productivity of the feller-buncher was determined (Equation 2), that is, the rate of production per unit of time of the felling operation, which is extremely relevant both for forest planning and for forest management.

$$
E_{p}=\frac{v}{h}
$$

In which:

$E_{p}$ - effective productivity of the feller-buncher $\left(\mathrm{m}^{3} \mathrm{~h}^{-1}\right)$;

$v$ - volume of wood cut $\left(\mathrm{m}^{3}\right)$

$h$ - hours of work (h).

\section{Cost analysis}

The monetary values were expressed in commercial American dollar, official of the Central Bank of Brazil, sold per hour of work $\left(\mathrm{US} \$ \mathrm{~h}^{-1}\right.$ ) (CENTRAL BANK of BRAZIL, 2017). Therefore, the price of the foreign currency was considered as exchange rate and was measured in units and fractions of the national currency, which was $\mathrm{R} \$ 3.1932(27 / 09 / 2017)$.

The operating cost of the feller-buncher was estimated in accordance to the methodology of cost control on timber harvesting recommended by the Food and Agriculture Organization of the United Nations (FAO, 1992). These costs were classified into: fixed costs of depreciation; interest on capital; workmanship; insurance; and rates on property. Variable costs comprised the monetary values with fuel, maintenance and repairs, spare parts, and lubricating oils and greases. The economic life of the feller-buncher was estimated at five years, with resale value of $20 \%$ of the purchase price. Moreover, the social security contributions corresponded to $134 \%$ of the salary of the feller-buncher operator.

Interest on equity, arising from the use of the money invested in the feller-buncher, were calculated by the rate of interest determined by the Capital Asset Pricing Model (CAPM) described in Equation 3. With this in mind, the interest rate of $2.07 \%$, risk-free, was applied, issued by the Treasury Department of the United States of America for the period of five years (period of the economic life of the feller-buncher), of factor $\beta_{e} 1,12$ for forest product industries and the market risk premium of $4.52 \%$.

In which:

$$
K_{e}=k_{r f}+\beta_{e}\left(k_{m}-k_{r f}\right)
$$

$K_{e}$ - cost of equity;

$k_{r f}$ - risk-free interest rate

$\beta_{e}$ - systematic risk of the forest industry;

$k_{m}$ - expected return of a market portfolio;

$\left(k_{m}-K_{r f}\right)$ - market risk premium. 
The production cost of the operation, determining both the definition of the harvesting mode and the profitability of products from forest-based companies, was calculated by the ratio between the hourly operating cost and the effective productivity of the feller-buncher (Equation 4).

$$
P_{c o}=\frac{H_{o c}}{E_{p}}
$$

In which:

$P_{c o}$ - production cost of the operation with the feller-buncher $\left(\mathrm{US} \$ \mathrm{~m}^{-3}\right)$;

$H_{o c}$ - hourly operating cost of the feller-buncher $\left(\mathrm{US} \$ \mathrm{~h}^{-1}\right)$.

\section{Risk analysis}

The Monte Carlo method was applied to the model so that stochastic solutions could be incorporated, with 100,000 iterations performed through the @ Risk Copyright @ 2016 Palisade Corporation software (2016). The random number generator Mersenne Twister was employed, ensuring the same initial parameter for the model run. Thus, from the initial representation of the most important input variables, that is, effective productivity and hourly operating cost (inputs), a stochastic model was built to express the production cost of the operation (output) in terms of probability.

For the series of values of the effective productivity, the Kolmogorov-Smirnov (K-S) test was used, at $1 \%$ level of significance to check the normality of the data. As for the hourly operating cost and the production cost of the operation, probability distributions were set by the Bayes Information Criterium (BIC). In order to measure the degree of linear association between inputs and outputs, Spearman's rank correlation coefficient was used $\left(\rho_{S}\right)$, at the significance level of $5 \%$.

\section{RESULTS}

\section{Working hours of the operating cycle}

During the period of field study, the total effective working time was 6 hours and 45 minutes. In flat relief, it was estimated that at least 100 work cycles would be required. However, 268 cycles were observed. Regarding the undulating relief, the minimum number of work cycles required was 58. However, 238 cycles were observed. During this period, 1,915 trees were felled in the flat relief, which corresponded to $478.7 \mathrm{~m}^{3}$, while in the undulating relief 1,735 trees were felled, which represented $381.7 \mathrm{~m}^{3}$.

Among the global distribution of the total effective time of the monitored working cycles, the mean times for felling the trees were the most representative in both reliefs analyzed (Table 1). Moreover, the times differed statistically among the reliefs $(\mathrm{p}<0.05)$, followed by the time spent to accumulate the bundles of trees, which were similar to each other by Tukey test at $5 \%$ of probability of error.

Table 1. Descriptive statistics of the times (minutes) of the feller-buncher work cycle elements.

Tabela 1. Estatística descritiva dos tempos (minutos) dos elementos do ciclo de trabalho do feller buncher.

\begin{tabular}{lcccccccc}
\hline \multirow{2}{*}{$\begin{array}{l}\text { Descriptiv } \\
\text { e statistics }\end{array}$} & Felling & \begin{tabular}{c} 
Dumpin \\
\cline { 2 - 9 } $\mathbf{g}$
\end{tabular} & $\begin{array}{c}\text { Returnin } \\
\mathbf{g}\end{array}$ & $\begin{array}{c}\text { Accumul } \\
\text { ating }\end{array}$ & Felling & Dumping & $\begin{array}{c}\text { Returnin } \\
\text { g }\end{array}$ & $\begin{array}{c}\text { Accumul } \\
\text { ating }\end{array}$ \\
\hline Mean & $0.46 \mathrm{~b}$ & $0.09 \mathrm{~b}$ & $0.12 \mathrm{a}$ & $0.30 \mathrm{a}$ & $0.52 \mathrm{a}$ & $0.10 \mathrm{a}$ & $0.10 \mathrm{~b}$ & $0.23 \mathrm{a}$ \\
SD & 0.09 & 0.03 & 0.06 & 0.18 & 0.13 & 0.04 & 0.07 & 0.16 \\
Min. & 0.12 & 0.05 & 0.05 & 0.10 & 0.13 & 0.03 & 0.03 & 0.05 \\
Max. & 0.82 & 0.22 & 0.37 & 0.72 & 1.27 & 0.30 & 0.55 & 0.58 \\
P5 & 0.33 & 0.05 & 0.07 & 0.13 & 0.36 & 0.05 & 0.03 & 0.08 \\
P95 & 0.63 & 0.15 & 0.22 & 0.65 & 0.75 & 0.18 & 0.22 & 0.58 \\
\hline
\end{tabular}

SD: standard deviation; min: minimum; max: maximum; P5: 5\% percentile; P95: 95\% percentile. Means followed by the same letter in the line do not differ statistically at $5 \%$ of significance by the Tukey test.

\section{Effective productivity}

The data adherence to the Normal distribution was confirmed by the Kolmogorov-Smirnov test, for the values of effective productivity observed in flat relief $(\mathrm{K}-\mathrm{S}=0.07)$ and undulating relief $(\mathrm{K}-\mathrm{S}=0.05)$. When considering the effective productivity in the flat relief, Normal distribution fitted the best $(\mathrm{BIC}=2391.95)$, with a mean of $160.43 \mathrm{~m}^{3} \mathrm{~h}^{-1}$ and standard deviation of $23.61 \mathrm{~m}^{3} \mathrm{~h}^{-1}$, and with a symmetric curve around the mean. 
Regarding the effective productivity observed in the undulating relief, Normal distribution fitted the best $(B I C=2218.77)$, with a mean of $132.88 \mathrm{~m}^{3} \mathrm{~h}^{-1}$ and standard deviation of $26.60 \mathrm{~m}^{3} \mathrm{~h}^{-1}$.

\section{Hourly operating cost and timber harvesting cost}

Based on the probabilistic value of the feller-buncher's hourly operating cost, and taking into account the selection criterion of BIC models, it was observed that the Normal distribution fitted the best, with a mean of US\$81.74 $\mathrm{h}^{-1}$ and standard deviation of US $\$ 2.34 \mathrm{~h}^{-1}$, which allowed the symmetric modeling of the data (Figure 1).

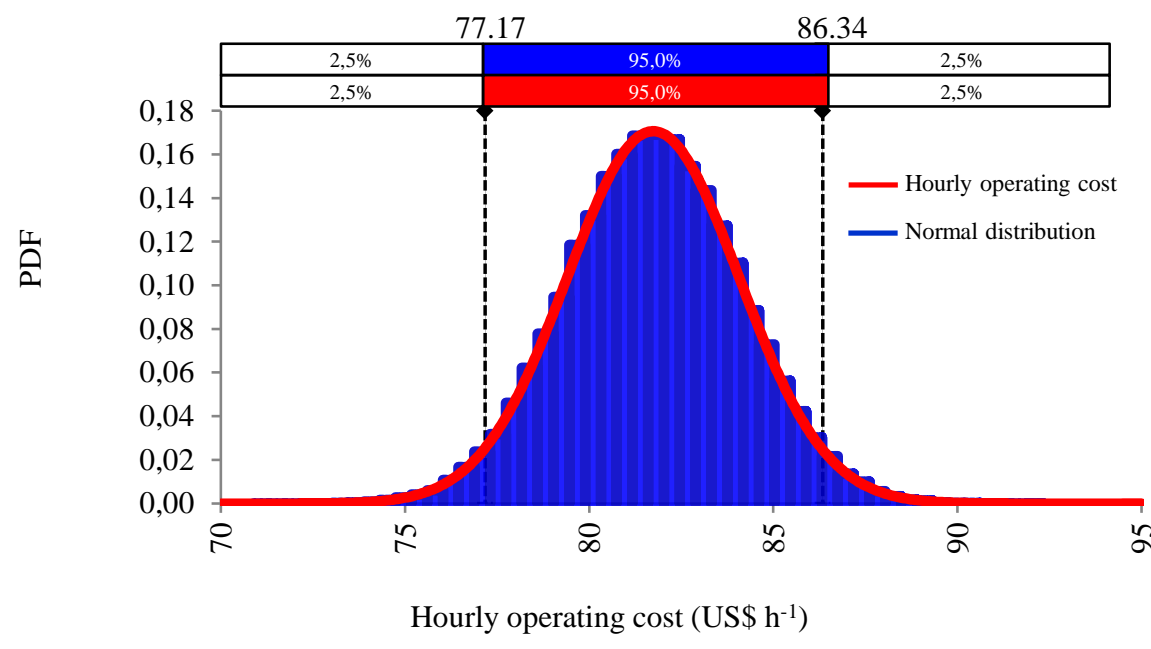

Figure 1. Probability Density Function (PDF) of the feller-buncher's hourly operating cost.

Figura 1. Função Densidade de Probabilidade (FDP) do custo operacional horário do feller buncher.

In the tornado diagram (Figure 2), the individual effect of each item of the feller buncher's hourly operating cost can be observed. At the upper end, the item with the greatest influence in the stochastic model is presented, while the lower end presents the item with the least influence. The maximum and minimum limits of each item are expressed by the distance between the line of the mean value (dashed line) and the value that can be obtained (ends of the vertical bar), which did not present symmetry for the analyzed condition.

Consequently, the fuel cost was the input with the highest statistically significant positive correlation $\left(\rho_{s}\right.$ $=0.91)(\mathrm{p}$-value $<0.01)$. Moreover, this input represented $50.4 \%$ of the hourly operating cost, followed by depreciation $\left(\rho_{s}=0.29\right)$, which accounted for $17.1 \%$ of the hourly operating cost. Regarding the expenses with spare parts, maintenance, and repairs, sensitivity analysis demonstrated a positive correlation with the variable of interest of 0.19 and 0.13 , respectively, which corresponded to $19 \%$ of the hourly operating cost.

In the analysis, the return on capital, that is, the interest on equity, estimated through CAPM, resulted in a rate of $11.4 \%$, demonstrating a low positive correlation $\left(\rho_{s}=0.09\right)$ with the hourly operating cost. The remaining cost items resulted in correlations considered to be weak $\left(\rho_{s} \leq 0.08\right)$. However, such cost items may influence the final value under analysis: the production cost of the feller-buncher operation. 


$$
\begin{array}{r}
\text { Fuel }\left(\mathrm{US} \$ \mathrm{~h}^{-1}\right) \\
\text { Depreciation }\left(\mathrm{US} \$ \mathrm{~h}^{-1}\right) \\
\text { Spare parts }\left(\mathrm{US} \$ \mathrm{~h}^{-1}\right)
\end{array}
$$

Maintenance and repairs $\left(\mathrm{US} \$ \mathrm{~h}^{-1}\right)$

Interest on capital $\left(\mathrm{US} \$ \mathrm{~h}^{-1}\right)$

Lubricantig oils and greases $\left(\mathrm{US} \$ \mathrm{~h}^{-1}\right)$

$$
\begin{array}{r}
\text { Workmanship }\left(\mathrm{US} \$ \mathrm{~h}^{-1}\right) \\
\text { Insurance }\left(\mathrm{US} \$ \mathrm{~h}^{-1}\right) \\
\text { Rates on property }\left(\mathrm{US} \$ \mathrm{~h}^{-1}\right)
\end{array}
$$

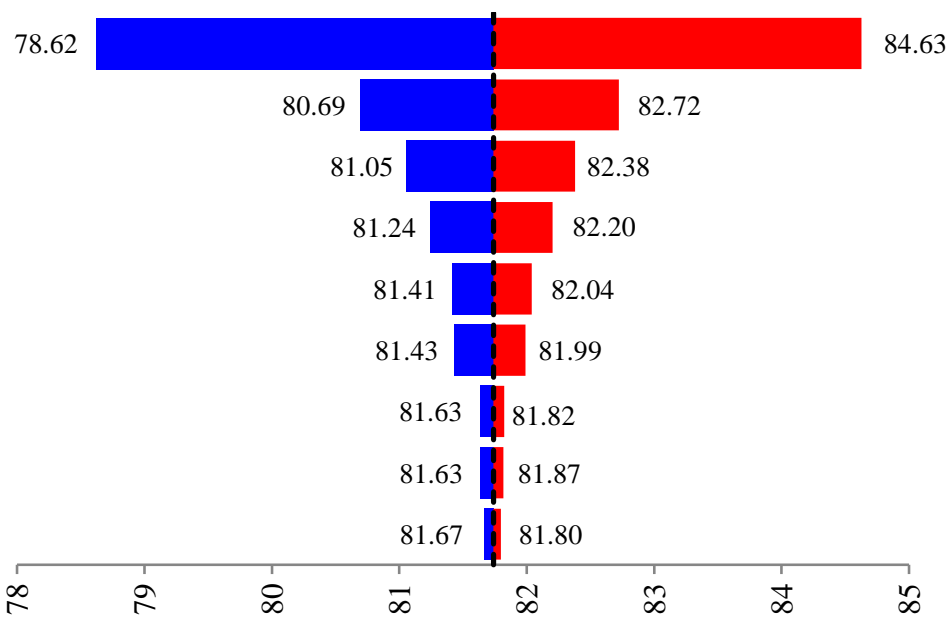

Hourly operating cost $\left(\mathrm{US} \$ \mathrm{~h}^{-1}\right)$

Figure 2. Individual effect of the cost items over the feller-buncher's mean hourly operating cost.

Figura 2. Efeito individual dos itens de custo sobre o custo operacional horário médio do feller buncher.

As for the production cost of the operation, both in flat relief and undulating relief, the mean and the standard deviation of the Lognormal distribution were adjusted (Figure 3). For the flat relief, the mean production cost of the operation was US $\$ 0.52 \mathrm{~m}^{-3}$ and the standard deviation was US\$0.08 $\mathrm{m}^{-3}$, with $95 \%$ of the generated values falling below US\$0.67 $\mathrm{m}^{-3}$. The mean production cost of the operation for the undulating relief was US\$0.64 $\mathrm{m}^{-3}$ and the standard deviation was US $\$ 0.14 \mathrm{~m}^{-3}$, with $95 \%$ of the probabilistic values lower than US\$0.91 $\mathrm{m}^{-3}$.

When considering the relationship between the production cost of the operation for the flat relief and the feller-buncher's effective productivity, a negative coefficient of Spearman's rank-order correlation was obtained ( $\rho_{s}$ $=-0.98)$. For the hourly operating cost, this coefficient was positive $\left(\rho_{s}=0.18\right)$. For the undulating relief, these inputs presented similar values to the ones for flat relief, with coefficients of -0.99 and 0.14 , respectively.

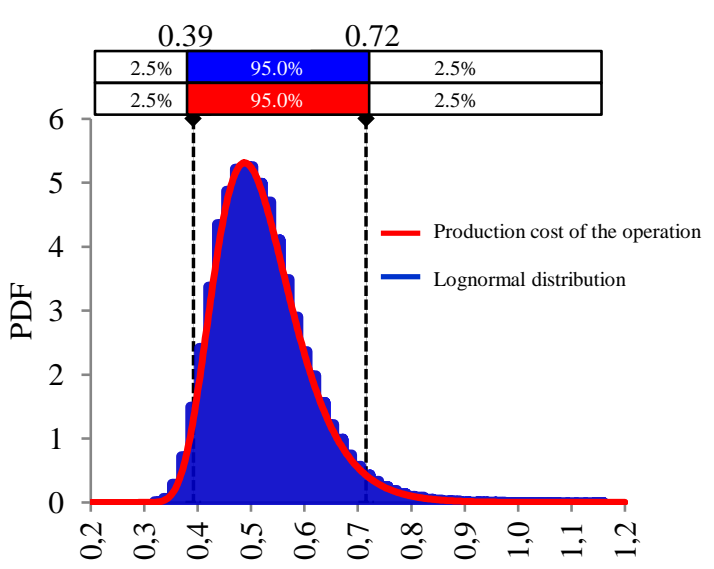

Production cost of the operation in flat relief $\left(\mathrm{US} \$ \mathrm{~m}^{-3}\right)$

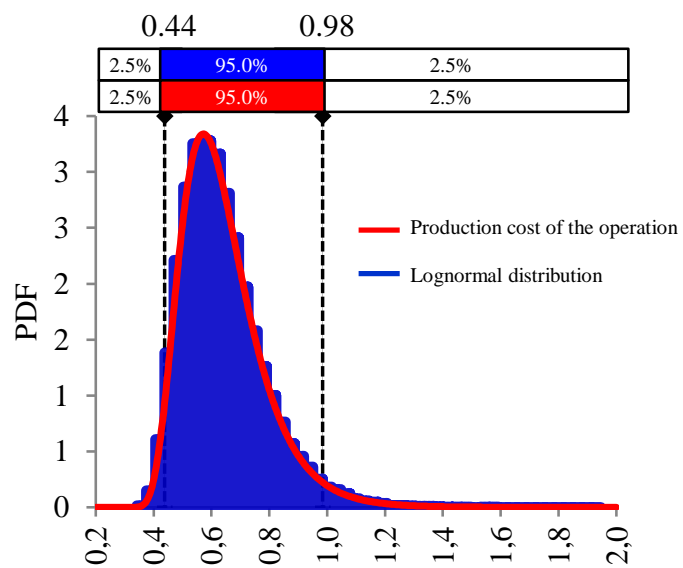

Production cost of the operation in undulating relief $\left(\mathrm{US} \$ \mathrm{~m}^{-3}\right)$

Figure 3. Probability Density Function (PDF) of the production costs of the operation with the feller-buncher in flat and undulating relief.

Figura 3. Função Densidade de Probabilidade (FDP) dos custos de produção da operação com feller buncher em relevo plano e relevo ondulado. 


\section{DISCUSSION}

In the analysis of the sample size, the initial estimate proved to be necessary in order to obtain accurate results. However, due to the technical conditions offered for the development of the study, a larger sample size was chosen. Such choice ensured a greater confidence in the estimate of the times of the work cycle elements, due to the reduction of the desired maximum error, which resulted in $3.1 \%$ for the observations in flat relief and $2.4 \%$ for the measurements obtained in undulating relief.

Thus, the scientific study of times and movements provided detailed information about the elements of the work cycle, such as the time of the related activity, that is, the time spent to fell the trees, which demanded $67.1 \%$ of the effective time of work during the harvest in flat relief and $70.8 \%$ in undulating relief. These percentages are similar to the results of Nascimento et al. (2011), who found that $65 \%$ of the time was spent in felling the trees, with the tipping of the bundles forming a $90^{\circ}$ angle with the planting row. The percentages are also similar to the findings of Simões et al. (2010), who found an average percentage of $68.2 \%$ for this element, with the feller-buncher in an extension composed of three tree rows. Therefore, the difference between the times of this element of the work cycle can be explained by the relief categories, since the harvest was conducted in a homogeneous forest with similar climatic conditions and, especially, monitored by the same feller-buncher operator.

The element returning to cutting position was the second most representative among the elements of the work cycle, for it consumed $17.4 \%$ of the time for the flat relief and $15.2 \%$ for the undulating relief. The most likely factor for this expense is the angle for the dumping of the bundles of trees, because the angle can increase or decrease the time of this element and, according to Lima and Leite (2014), angles of $45^{\circ}$ or $90^{\circ}$ can be formed in relation to the plating row. However, the angle for the dumping of these bundles is associated with simplifying the subsequent operation, which may be the bucking of wood within the tree stand or the skidding of the trees to the roadside. The dumping element consumed an average of $12.6 \%$ of the time, followed by the time spent to accumulate the bundles of trees, which demanded $2.3 \%$ of the effective time of work.

Therefore, the study of times and movements, which can be considered as the basis of the rationalization of the productive factors, enabled to determine the effective productivity, modeled by a probability distribution that determined the average effective productivity and the dispersion of the data. Thus, the stochastic values were higher than those found by Simões et al. (2014) e Miyajima et al. (2016), whose studies were conducted in similar conditions of equipment, relief and forest stand. It is worth noting that the effective productivity of the machines used in timber harvesting is influenced by several factors, such as the slope of the terrain, the soil type, the experience of the operator, the tree volume, among others that can be previously identified, but with different degrees of precision. However, these factors can be evaluated by methods that allow the evaluation and measurement of operational risks.

Regarding the hourly operating cost of the machines used in timber harvesting, there are different methodologies for this calculation. However, Ackerman et al. (2014) stress that the results given by each of them are slightly different. This characteristic can be explained due to the several factors that compose this hourly operating cost, which should be evaluated as sources of uncertainty. If not treated as such, the analyses will be subject to varied errors, such as the analysis of timber harvesting cost, for example.

Thus, by assigning a probability distribution for each source of uncertainty, that is, for each item composing the hourly operating cost, a range of occurrence of the value under analysis was obtained and, therefore, a probability distribution was adjusted for the hourly operating cost of the feller-buncher. As a result, the probabilistic value of the hourly operating cost was between US\$77.17 $\mathrm{h}^{-1}$ and US $\$ 86.34 \mathrm{~h}^{-1}$, with a probability of $95 \%$. The hourly operating cost values found by Seixas and Batista (2014) for three feller-buncher models are within this range. These authors used the same methodology of the present study, but in a deterministic way.

From the average value, the fuel cost, for being the input with the greatest effect over the hourly operating cost, underwent a positive change of up to $3.8 \%$ and a negative change of up to $3.5 \%$. By keeping the remaining inputs unchanged, the hourly operating cost could increase by US $\$ 2.89$, but it would provide a reduction of US\$3.12 per hour of work. Analogously, the depreciation is another input that should be monitored due to the positive effect of up to $1.3 \%$ and the negative effect of $1.2 \%$. Therefore, the hourly operating cost would be reduced by US\$1.05 or would increase US\$0.98 per hour of work. The remaining inputs resulted in both positive and negative variations lower than $1 \%$.

When analyzing a forest investment, managers establish a series of guidelines, such as the harvesting mode. However, the choice of the mode is associated with harvesting costs, which can derail both the capital investment and the price of the final product. Thus, the analysis of harvesting costs conducted from stochastic variables allowed the establishment of probabilities of occurrence and the association between the variables of interest. Therefore, the probabilistic value of the production cost of the operation in flat relief varied $15.4 \%$, while in undulating relief the variation was $21.9 \%$, compared to their respective mean values.

FLORESTA, Curitiba, PR, v. 48, n. 3, p. 403-412, jul/set. 2018

Simões. D. et.al.

ISSN eletrônico 1982-4688

DOI: $10.5380 /$ rf.v48i3.56404 
The Monte Carlo technique provided results based on probabilities and associations, such as the degree of relationship between the effective productivity and the production cost of the operation. These results showed negative association coefficients and are considered strong for having a monotonic relationship, that is, these variables tend to have a contiguous increasing or decreasing behavior.

\section{CONCLUSIONS}

- The application of the Monte Carlo method allowed obtaining probabilistic distributions that describe the behavior of the variables of interest. Also, it allowed a plausible analysis of the production process and related costs, since it is based on the calculation of probabilities of occurrence of the events of these variables.

- Based on the mean probabilistic value, it was verified that the behavior of the production cost of the operation in flat relief was lower than the production cost of the operation in undulating relief.

- The fuel cost was the most relevant variable in terms of economic risk, for it presented a strong positive correlation coefficient with hourly operating cost.

\section{REFERENCES}

ACKERMAN, P.; BELBO, H.; ELIASSON, L.; JONG, A.; LAZDINS, A.; LYONS, J. The COST model for calculation of forest operations costs. International Journal of Forest Engineering, USA, v. 25, n. 1, p. 75-81, 2014.

BANCO CENTRAL do BRASIL. Conversão de moedas. Disponível em: <http://www4.bcb.gov.br/pec/conversao/conversao.asp> Acesso em: 28/09/2017.

CHENG, M. Y., ROY, A. F. V. Evolutionary fuzzy decision model for construction management using support vector machine. Expert Systems with Applications, USA, v. 37, n. 8, p. 6061-6069, 2010.

FOOD AND AGRICULTURE ORGANIZATION OF THE UNITED NATIONS. Cost control in forest harvesting and road construction. Rome: Food and Agriculture Organization of the United Nations, Forestry Paper 99, 1992, $121 \mathrm{p}$.

HIESL, P.; BENJAMIN, J. G. Applicability of international harvesting equipment productivity studies in Maine, USA: a literature review. Forests, Florida, v. 4, p. 898-921, 2013.

KWAK, Y. H.; INGALL, L. Exploring Monte Carlo Simulation Applications for Project Management. IEEE Engineering Management Review, USA, v. 37, n. 2, p. 83-91, Second Quarter, 2009.

LEITE, E. S.; FERNANDES, H. C.; MINETTE, L. J.; LEITE, H. G.; GUEDES, I. L. Modelagem técnica e de custos do Harvester no corte de madeira de eucalipto no sistema de toras curtas. Scientia Forestalis, Piracicaba, v. 41, n. 98, p. 205-215, 2013.

LEITE, E. S.; FERNANDES, H. C.; MINETTE, L. J.; SOUZA, A. P. S.; LEITE, H. G. L.; GUEDES, I. L. Modelagem do desempenho da extracao de madeira pelo forwarder. Revista Árvore, Viçosa, v. 38, n. 5, p. 879$887,2014$.

LIMA, S. S.; LEITE, A. M. P. Mecanização. In: MACHADO, C. C. Colheita florestal. Viçosa: Ed. UFV, 2014, $543 \mathrm{p}$.

LOIZOU, P.; FRENCH, N. Risk and uncertainty in development: a critical evaluation of using the Monte Carlo Simulation Method as a decision tool in real estate development projects. Journal of Property Investment \& Finance, German, v. 30, n. 2, p. 198-201, 2012.

MIYAJIMA, R. H.; TONIN, R. P.; PASSOS, J. R.; FENNER, P. T. A influência da declividade do terreno e do tempo de experiência dos operadores no rendimento do feller buncher. Scientia Forestalis, Piracicaba, v. 44, n. 110, p. 443-451, 2016.

MOUSAVI, R. Time consumption, productivity, and cost analysis of skidding in the Hyrcanian forest in Iran. Journal of Forestry Research, China, v. 23, n. 4, p. 691-697, 2012.

NASCIMENTO, A. C.; LEITE, A. M. P.; SOARES, T. S.; FREITAS, L. C. Avaliação técnica e econômica da colheita florestal com feller-buncher. Cerne, Lavras, v. 17, n. 1, p. 9-15, 2011. 
OLIVEIRA JÚNIOR, E. D.; SEIXAS, F.; BATISTA, J. L. F. Produtividade de feller-buncher em povoamento de eucalipto em relevo acidentado. Floresta, Curitiba, v. 39, n. 4, p. 905-912, 2009.

PAJARES, J.; LÓPEZ-PAREDES A. An extension of the EVM analysis for project monitoring: The Cost Control Index and The Schedule Control Index. International Journal of Project Management, Austria, v. 29, p. 615621, 2011.

PALISADE CORPORATION. @ Risk. Newfield: Palisade Corporation. Versão 7.5, 2016.

SANTOS, D. W. F. N.; VALENTE, D. M. S.; FERNANDES, H. C.; FORASTIERE, P. R.; SILVA, R. M. F. Análise técnica e econômica do harvester operando em dois subsistemas de colheita de madeira. Engenharia na Agricultura, Viçosa, v. 24, n. 6, p. 484-490, 2016.

SANTOS, H. G.; ALMEIDA, J. A.; OLIVEIRA, J. B.; LUMBRERAS, J. F.; ANJOS, L. H. C.; COELHO, M. R.; JACOMINE, P. K. T.; CUNHA, T. J. F.; OLIVEIRA, V. A. Sistema brasileiro de classificação de solos. Brasília: EMBRAPA, 3. ed. 2013, 353 p.

SEIXAS, F.; BATISTA, J. L. F. Comparação técnica e econômica entre harvesters de pneus e com máquina base de esteiras. Ciência Florestal, Santa Maria, v. 24, n. 1, p. 185-191, 2014.

SIMÕES, D.; IAMONTI, I. C.; FENNER, P. T. Avaliação técnica e econômica do corte de eucalipto com fellerbuncher em diferentes condições operacionais. Ciência Florestal, Santa Maria, v. 20, n. 4, p. 649-656, 2010.

SIMÕES, D.; FENNER, P. T.; ESPERANCINI, M. S. T. Produtividade e custos do feller-buncher e processador florestal em povoamento de eucalipto em primeiro corte. Ciência Florestal, Santa Maria, v. 24, n. 3, p. 621-630, 2014.

SPINELLI, R.; CUCHET, E.; ROUX, P. A new feller-buncher for harvesting energy wood: Results from a European test programme. Biomass Bioenergy, Scotland, v.31, p. 205-210, 2007.

STEVENSON, W. J. Administração das operações de produção. Rio de Janeiro: LTC, 2001, 701 p. 
FLORESTA, Curitiba, PR, v. 48, n. 3, p. 403-412, jul/set.2018

Simões. D. et.al 